\title{
CONSTANT CURRENT CHRONOPOTENTIOMETRY STUDY OF DNA FOR THE DETECTION OF AFRICAN SWINE FEVER VIRUS
}

\author{
${ }^{1}$ Ondrej RYCHLY, ${ }^{1,2,5}$ Bozena HOSNEDLOVA, ${ }^{3}$ Arli Aditya PARIKESIT, ${ }^{2}$ Milan JAKUBEK, \\ ${ }^{4}$ Marta KEPINSKA, ${ }^{5}$ Petra VASICKOVA, ${ }^{1,2,4,5}$ Rene KIZEK \\ ${ }^{1}$ CONEM Metallomics Nanomedicine Research Group (CMNRG), Vinohrady, Prague, Czech Republic, EU, \\ rychly@seznam.cz \\ ${ }^{2}$ BIOCEV, First Faculty of Medicine, Charles University, Vestec, Czech Republic, EU, \\ bozena.hosnedlova@post.cz;milan.jakubek@lf1.cuni.cz \\ ${ }^{3}$ Department of Bioinformatics, School of Life Sciences, Indonesia International Institute for Life Sciences, \\ Jakarta Timur, Indonesia, pakresit@el.ind \\ ${ }^{4}$ Department of Pharmaceutical Biochemistry, Division of Biomedical and Environmental Analyses, Faculty \\ of Pharmacy, Wroclaw Medical University, Wroclaw, Poland, EU, marta.kepinska@umw.edu.pl \\ ${ }^{5}$ Veterinary Research Institute, Brno, Czech Republic, EU, kizek@sci.muni.cz \\ *Correspondence: kizek@sci.muni.cz; Tel./Fax: +42-05-4156-2820
}

https://doi.org/10.37904/nanocon.2021.4357

\begin{abstract}
African Swine Fever Virus (ASFV) is a DNA virus of the Asfivirus genus of the Asfarviridae family that is found in blood, body fluids, and internal organs. ASFV was described more than 40 years ago. This virus spreads pandemically and the mortality rate of the virus-related disease ranges from 90 to $100 \%$. The aim of this study was to propose the detection of the specific nucleic acid of ASFV using electrochemical detection. Determination of DNA was conducted by chronopotentiometric stripping analysis (time of accumulation $120 \mathrm{~s}$, stripping current $20,10,5,1 \mu \mathrm{A}$, measurement time $240 \mathrm{~s}$ ). The volume of the analyzed sample was $10 \mu \mathrm{L}$. Sufficient analysis duration (200-600 s) is required to fully record the $\mathrm{H}$ peak signal of DNA at a given applied current. Extending the DNA analysis time at a given current significantly improved the $\mathrm{dt} / \mathrm{dE}$ records of the $\mathrm{H}$ peak and the reproducibility of the analysis (RSD up to $10 \%$ ). It was found that the suitable time at which the $\mathrm{H}$ peak is plotted reliably is around $240 \mathrm{~s}$. The detected dsDNA concentration dependence $(0$ to $60 \mu \mathrm{g} / \mathrm{mL})$ on the catalytic signal of the $\mathrm{H}$ peak was described according to the equation $\mathrm{y}=260.4+366.7 \mathrm{x}, \mathrm{r}=0.961$, RSD $23.1 \%$. Subsequently, the SPION particle was modified with dsDNA. After the thermal release of DNA from SPION, DNA was immediately determined by chronopotentiometric stripping analysis method.
\end{abstract}

Keywords: Emergency biosensor; nucleic acid; oligonucleotide; superparamagnetic nanoparticle

\section{INTRODUCTION}

African swine fever (ASF) is a highly dangerous swine disease occurring on various continents. The African swine fever virus (ASFV) is known mainly for its infectivity and high mortality of the Suidae family. ASF first appeared in the sub-Saharan region of Africa [1] and from there the disease spread through the Transcaucasian region to Russia, Europe and Asia. ASF is already spreading in the Pacific. There is a growing concern that the disease will spread to other areas as a result of travel and imports of pork products from countries where ASF is present. In wild boars, the situation is out of control in many countries. The causative agent of ASFV is an enveloped cytoplasmic double-stranded DNA arbovirus (Asfavirus) (genome size 170$193 \mathrm{kbp}$ ), which is the only member of the Asfarviridae family (Figure 1). Anti-epidemiological measures 
include disinfection regimes, partial or complete quarantine in the areas concerned and the consistent eradication of susceptible individuals at the outbreak. Early diagnosis is key to performing these measures. Commonly used virus identification techniques are based on the detection of viral nucleic acid by PCR or are based on the detection of viral antigens by immunological techniques. The specificity and sensitivity of these methods is very good, but they require laboratory facilities and qualified personnel. Electrochemical detection of nucleic acids is based on the redox properties of the nucleic bases present in DNA or RNA [2,3]. Until almost the late 1950s, nucleic acids were considered electrochemically inert and too large to be analyzed by electrochemistry. In 1958 Professor Emil Paleček found that the nuclear bases adenine and cytosine are electrochemically reduced [4,5]. Typical reduction signals of adenine and cytosine [6] are observable as a signal with a maximum in the region of about $-1.30 \mathrm{~V}$ [7]. Later, Professor Trnkova described the detailed electrochemical behavior of guanine [6]. Both these discoveries helped to develop a completely new field of bioanalytical chemistry: sensors and biosensors. In contrast, electrochemical biosensors (do not require qualified BSL-2 laboratories) and can also speed up the detection of dangerous viruses $[8,9]$. The aim of this work was to propose the use of chronopotentiometric stripping analysis (CPSA) for sensitive detection of dsDNA.

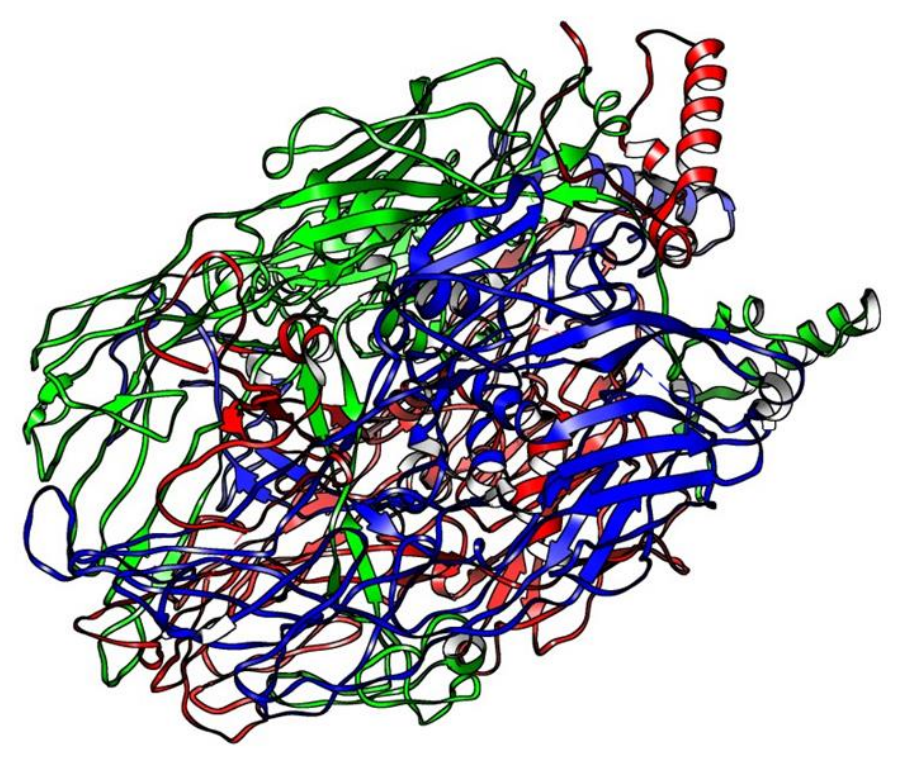

Figure 1 The most important capsid virion protein of the African Swine Fever Virus (ASFV) is depicted from the Protein Data Bank (PDB repository (https://www.rcsb.org/). P72 is the most abundant capsid virion antigenic in swine and considered the most important biomarker for the disease diagnosis (PDB ID: 6I2t). The 3-D visualization of the ASFV capsid virion protein p72 in the resolution of $4.1 \AA$, where the hydrogen bond could be examined accordingly $[10,11]$.

\section{MATERIALS AND METHODS}

\subsection{Chemicals and chemical analysis}

All chemicals used in this study such as Trizma base, trisodium citrate, hydrogen tetrachloroaurate(III) $\left(\mathrm{HAuCl}_{4}\right)$, acetic acid $(\mathrm{HAc})$, sodium acetate $(\mathrm{NaOAc})$, tris(2-carboxyethyl)phosphine hydrochloride (TCEP), ethylenediaminetetraacetic acid (EDTA), disodium hydrogen phosphate $\left(\mathrm{Na}_{2} \mathrm{HPO}_{4}\right)$, potassium dihydrogen phosphate $\left(\mathrm{KH}_{2} \mathrm{PO}_{4}\right)$, sodium chloride $(\mathrm{NaCl})$, potassium chloride $(\mathrm{KCl})$, and $\mathrm{HCl}$ were purchased from SigmaAldrich (St. Louis, MO, USA), in ACS purity. Deionised water was prepared by using the reverse osmosis equipment Aqual 25 (Brno, Czech Republic), and was further purified by using an ELGA apparatus equipped with a UV lamp (Lane End, United Kingdom). The resistance was $18 \mathrm{M} \Omega$ and the $\mathrm{pH}$ was measured using the $\mathrm{pH}$ meter VWR (Radnor, USA). 


\subsection{Spectrometry measurement}

The absorption spectra, in the wavelength range of 200 to $800 \mathrm{~nm}$ was measured. For fluorescence spectra, there was an excitation wavelength of $250 \mathrm{~nm}$ and an emission wavelength in the range from 350 to $800 \mathrm{~nm}$ (Varioskan, Thermo Fisher Scientific, USA). The optical properties of nanoparticles were studied by spectral analysis.

\subsection{Electrochemical measurement}

Electrochemical measurements were performed with an AUTOLAB Analyser connected to VA-Stand 663, using a standard cell with three electrodes. The working electrode was a hanging mercury drop electrode (HMDE) with a drop area of $0.4 \mathrm{~mm}^{2}$. The reference electrode was an $\mathrm{Ag} / \mathrm{AgCl} / 3 \mathrm{M} \mathrm{KCl}$ electrode, and the auxiliary electrode was a graphite electrode. The supporting electrolyte containing $0.2 \mathrm{M}$ Mcllvaine buffer $(\mathrm{pH}$ 7.0) was used. CPSA: time of accumulation $120 \mathrm{~s}$, stripping current $20,10,5$ and $1 \mu \mathrm{A}$, measurement time $240 \mathrm{~s}$.

\subsection{Zetasizer analysis}

The size distribution (i.e., the hydrodynamic diameter, DH) was determined by dynamic light scattering (DLS) using the Zetasizer Nano ZS ZEN3600 (Malvern Instruments, Malvern, UK) with the detection angle of $173^{\circ}$ in optically homogeneous square polystyrene cells. The samples have diluted a hundredfold with deionized water. All measurements were performed at $25^{\circ} \mathrm{C}$. Each value was obtained as an average of 5 runs with at least 10 measurements. Version 7.10 of the Zetasizer Software was applied for data evaluation. The particle charge ( $\zeta$-potential) was measured by the microelectrophoretic method using a Malvern Zetasizer Nano ZS ZEN3600 (Malvern Instruments, Malvern, UK). All the measurements were performed at $25{ }^{\circ} \mathrm{C}$ in polycarbonate cuvettes. Each value was obtained as an average of 5 subsequent runs of the instrument with at least 20 measurements.

\subsection{Synthesis of SPIONs and SPION/DNA}

$1.3 \mathrm{~g}$ of $\mathrm{Fe}\left(\mathrm{NO}_{3}\right)_{3} \cdot 9 \mathrm{H}_{2} \mathrm{O}$ was dissolved in $80 \mathrm{~mL}$ of water $\left(18 \mathrm{M} \Omega\right.$ ). A quantity of $1.4 \mathrm{~mL} 25 \% \mathrm{NH}_{3}$ was diluted in $8.6 \mathrm{~mL}$ water and $0.2 \mathrm{~g} \mathrm{NaBH}_{4}$ was dissolved in this mixture and, subsequently, the mixture was stirred (300 $\mathrm{rpm}, 10 \mathrm{~min}$ at $22^{\circ} \mathrm{C}$ ). The solution colour turned dark brown. The mixture was heated to $100{ }^{\circ} \mathrm{C}$ for $2 \mathrm{~h}$ and stirred (300 rpm, stirring overnight at room temperature). The magnetic particles were separated from the solution via a magnet and washed several times in water. The solution of $\mathrm{HAuCl}_{4}(20 \mathrm{~mL}, 1 \mathrm{mM})$ was added to the magnetic particles and stirred $\left(300 \mathrm{rpm} 3 \mathrm{~h}\right.$ at $22{ }^{\circ} \mathrm{C}$ ). Subsequently, the solution of $\mathrm{C}_{6} \mathrm{H}_{5} \mathrm{Na}_{3} \mathrm{O}_{7} \cdot 2 \mathrm{H}_{2} \mathrm{O}$ $(0.5 \mathrm{~mL}, 0.265 \mathrm{~g} / 10 \mathrm{~mL})$ was added to the mixture and stirred overnight. Finally, the gold SPIONs were separated via a magnet and dried $\left(40^{\circ} \mathrm{C}\right)$.

\subsection{Statistical data analysis}

Available experimental data were processed and evaluated mathematically and statistically directly in the Qinslab database. The exclusion of extreme values for data sets was performed by calculation in the Grubbs test. Experimental work was performed in at least three independent experiments $\left(n_{1}\right)$. Each sample in the experiments was analyzed at least five times $\left(n_{2}\right)$. The data presented in this work are presented as average values. LOD (limit of detection) values were determined according to the work of Hubaux and Vos [12] at a level of significance of $95 \%$. Data visualization was performed using the Qinslab database.

\section{RESULTS AND DISCUSSION}

Electrochemical biosensing of viral pathogens is summarized in a study by Campuzano et al. [13]. A viral pathogen can be detected by the presence of its nucleic acid. The designed biosensor allows recognition very easily [3]. The concept proposed by us is summarized in Figure 2. The SPION particle is modified with a 
specific ASFV antibody (most often to the 78 protein). The virus is captured on SPION and after the necessary washing steps is mechanically and physically inactivated and disrupted (thus guaranteeing specificity). The nucleic acid is released into solution and analyzed by CPSA. In view of the direct detection of the presence of a pathogen in a sample, it is necessary for these purposes to obtain a significant sensitivity of DNA detection, which is guaranteed by CPSA which is highly sensitive in the order of up to $f g$ in the analyzed sample. In several previous experimental works, we used mainly redox signals of nucleic acid bases (adenine, cytosine) [14]. The sensitivity of these approaches varies in submicrograms per $\mathrm{mL}$. Catalytic signals are known to increase the sensitivity of analyte detection [15]. Catalytic signals of hydrogen excretion have been described for proteins but also for nucleic acids $[16,17]$. We focused on the description of the basic behavior of the $\mathrm{H}$ peak induced by the presence of dsDNA (in Mcllvaine buffer, $\mathrm{pH}$ 7.0).

Electrochemical detection of viral DNA

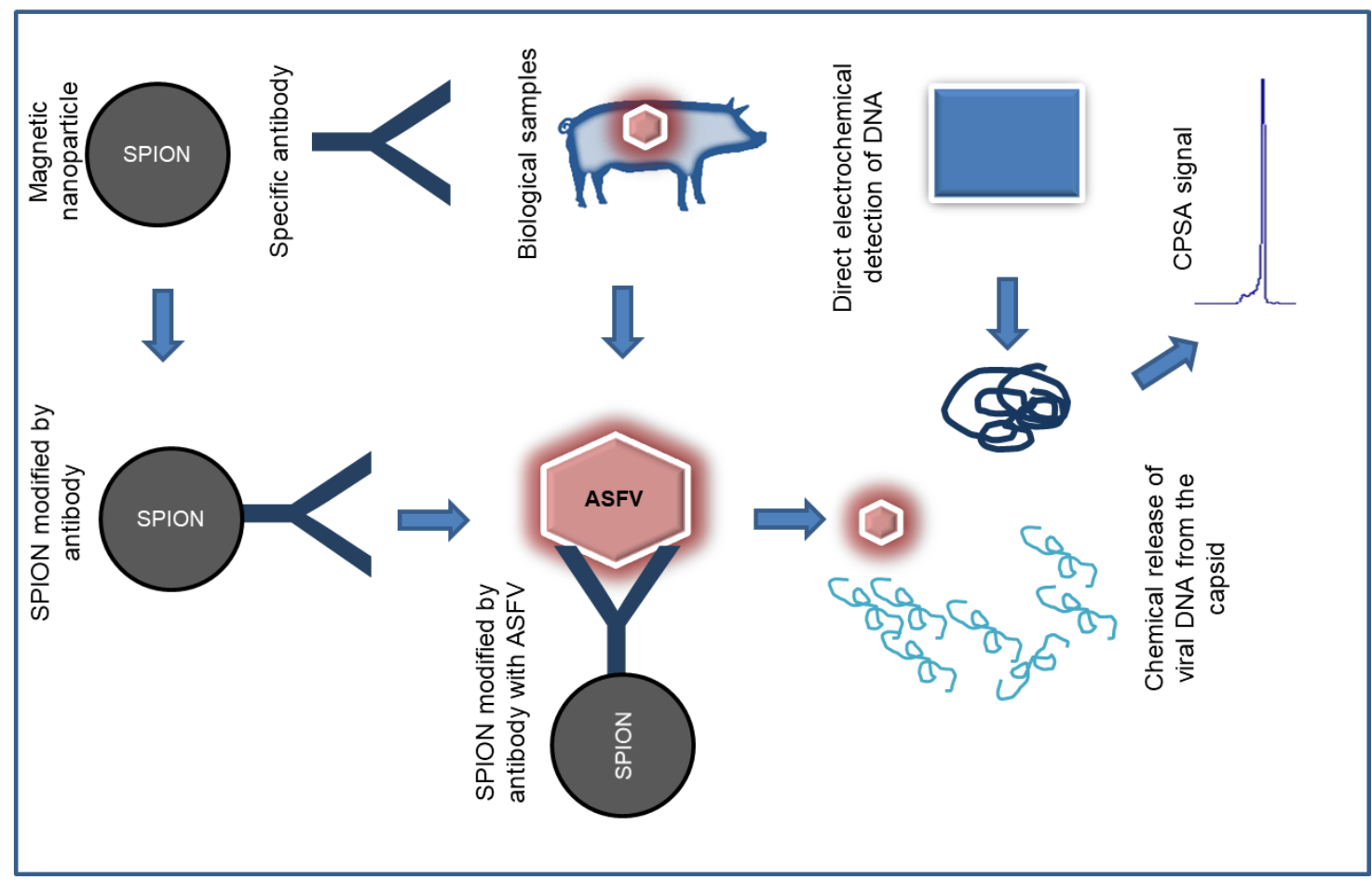

Figure 2 Scheme of presumed direct detection of viral DNA using electrochemical detection of CPSA. The procedure uses gold magnetic particles (SPIONs) modified with a specific antibody to the ASFV. A biological sample (homogenate) containing ASFV is incubated with SPION. Bound ASFV to SPION is subsequently disintegrated to release genomic DNA. The obtained sample is analyzed electrochemically by CPSA.

Gold is known to adsorb to DNA through affinity interactions [18]. Some forms of interactions between ds-DNA and citrate coated gold nanoparticles have been reported [19-25]. Different electrointeractions between the surface of gold nanoparticles (having a positive charge) and DNA that has a negative charge, were demonstrated. Gold nanoparticles are known for their excellent biocompatibility with biomolecules and possess remarkable structural, electronic, magnetic, optical and catalytic properties [26]. Caballero et al. [27] found that a-lipoic acid/aminoanthraquinone functionalized gold nanoparticles caused notable coiling/wrapping of DNA despite their anionic surface charge. The functionalization of magnetic nanoparticles with gold was demonstrated through the conjugation of thiolated DNA to the gold shell [28]. Synthesis Deghan et al. reported that SPIONs doped with $2 \mathrm{H}$-chromene via dopamine as cross linker bound to calf thymus DNA via groove binding mode [29]. Regarding ssDNA and dsDNA interactions with AuNPs, dsDNA has (due to its double helix structure, which exposes the negative charges of the phosphate groups to the outside) greater rigidity than ssDNA, which makes it difficult to interact with the surface of anionic AuNPs. In addition to affecting the electrostatic component of this interaction, Van der Waals forces are also affected by the presence of non- 
polar regions in DNA. In the case of cationic AuNPs, electrostatic forces prefer the molecular approach [30-32]. The presence of cationic NPs causes partial denaturation of the DNA helix, resulting in a number of intermediate structures between ss and dsDNA [31]. Electrostatic interactions lead to DNA bending, whereas hydrophobic interactions with bases in the grooves deform the DNA structure [30,31].
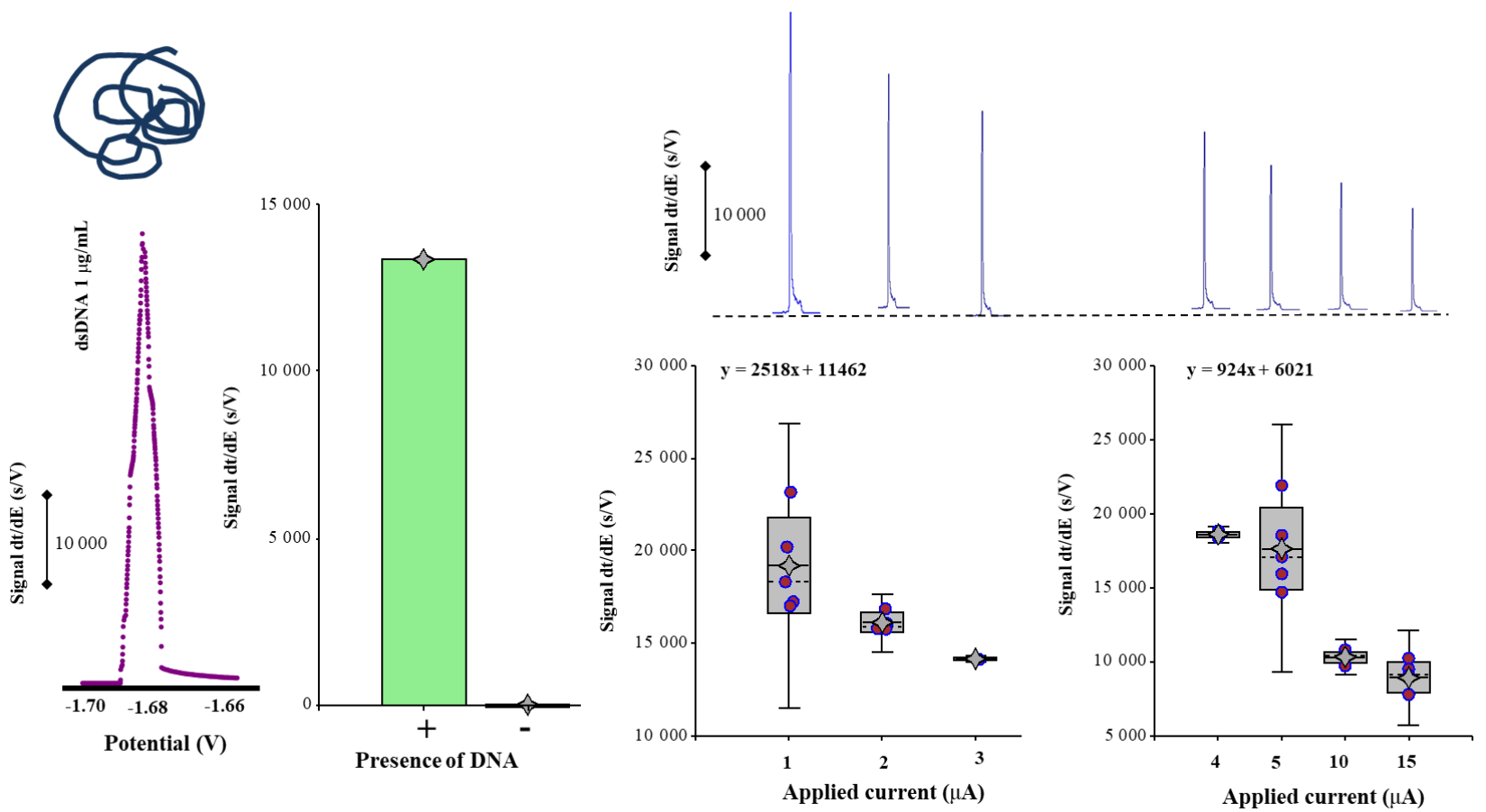

Figure 3 Typical CPSA signal (peak $\mathrm{H}$ ) of genomic dsDNA $(1 \mu \mathrm{g} / \mathrm{mL})$, basic electrolyte (black line) at a measurement time of $120 \mathrm{~s}$. CPSA peak $\mathrm{H}$ was tested in the presence and absence of dsDNA $(n=10)$. Changes of the $\mathrm{H}$ peak signal on the applied current (at measurement times 180 and $360 \mathrm{~s}$ ). At the top of the figure, there are typical peaks of $\mathrm{H}$ at a given current.

Several different signals appear on the obtained chronopotentiogram of DNA (10 $\mu \mathrm{g} / \mathrm{mL})$ (Figure 3). We verified that the presence of DNA in the sample leads to the catalytic signal of the $\mathrm{H}$ peak $(n=10)$. We further studied under which conditions (concentration of DNA in the sample, applied current used for analysis and maximum duration of analysis) different catalytic signals are generated and how the $\mathrm{H}$ catalytic peak of DNA changes. The applied current is essential for the subsequently detected dt/dE signal (Figure 3). The applied current suitable for analysis varies according to the amount of dsDNA present in the sample. We tested different applied currents $(20,10,5$ and $1 \mu \mathrm{A})$. At a DNA concentration of less than $1 \mu \mathrm{g} / \mathrm{mL}$, we achieved the best-plotted $\mathrm{H}$ peaks (dt/dE) at a current of $5 \mu \mathrm{A}$. Different current values were applied in two independent experiments: $10 \mu \mathrm{A}$ for DNA concentrations of 1,5 and $10 \mu \mathrm{g} / \mathrm{mL}$, and $15 \mu \mathrm{A}$ for concentrations of 10,15 and $20 \mu \mathrm{g} / \mathrm{mL}$. For DNA concentrations above $20 \mu \mathrm{g} / \mathrm{mL}$, the best responses were obtained when applying a current of $20 \mu \mathrm{A}$. Sufficient analysis duration (dependence of a potential $E$ on a time $t$ ) is required to fully record the signal of the $\mathrm{H}$ peak of dsDNA at a given applied current. Extending the DNA analysis time at a given current significantly improved the $\mathrm{dt} / \mathrm{dE}$ records of the $\mathrm{H}$ peak and the reproducibility of the analysis (RSD up to $10 \%)$. It was found that the suitable time for which the $\mathrm{H}$ peak is reliably plotted is around $240 \mathrm{~s}$. The observed concentration dependence of DNA $(0$ to $60 \mu \mathrm{g} / \mathrm{mL})$ on the catalytic signal of the $\mathrm{H}$ peak was described according to the equation $y=260.4+366.7 x, r=0.961$, RSD $23.1 \%$ (Figure 4). To simulate the detection of dsDNA from the sample, SPIONs/DNA modified particles were prepared: $500 \mu \mathrm{g}$ of SPIONs was added to $100 \mu \mathrm{g} / \mathrm{mL}$ of dsDNA, the interaction was performed for $30 \mathrm{~min}, 25^{\circ} \mathrm{C}$ with gentle stirring; phosphate buffer $(\mathrm{pH} 5.0,0.2 \mathrm{M}, 200 \mu \mathrm{L})$ was used for the washing step. The tube was placed on a shaker $\left(25^{\circ} \mathrm{C}, 90 \mathrm{~s}\right.$, $300 \mathrm{rpm})$. The individual steps were repeated 3 times. The SPIONs/DNA was placed on a magnet and the 
liquid was aspirated, and then the elution phosphate buffer ( $\mathrm{pH} 5.0,0.2 \mathrm{M}$ ) was added. Due to the direct detection of DNA in the sample, DNA fragmentation may occur, which we do not consider to be a defect. The tube was placed in a thermoblock $\left(100{ }^{\circ} \mathrm{C}, 15 \mathrm{~min}, 350 \mathrm{rpm}\right)$. Subsequently, the sample was centrifuged at $16,000 \mathrm{~g}, 5 \mathrm{~min}, 4^{\circ} \mathrm{C}$, the tube with the sample was placed on a magnet, the liquid was pipetted and transferred to a clean tube.) The prepared final sample was analyzed by CPSA. A signal was recorded in the presence of DNA in the analyzed sample, while no signal appeared in its absence (Figure 4).
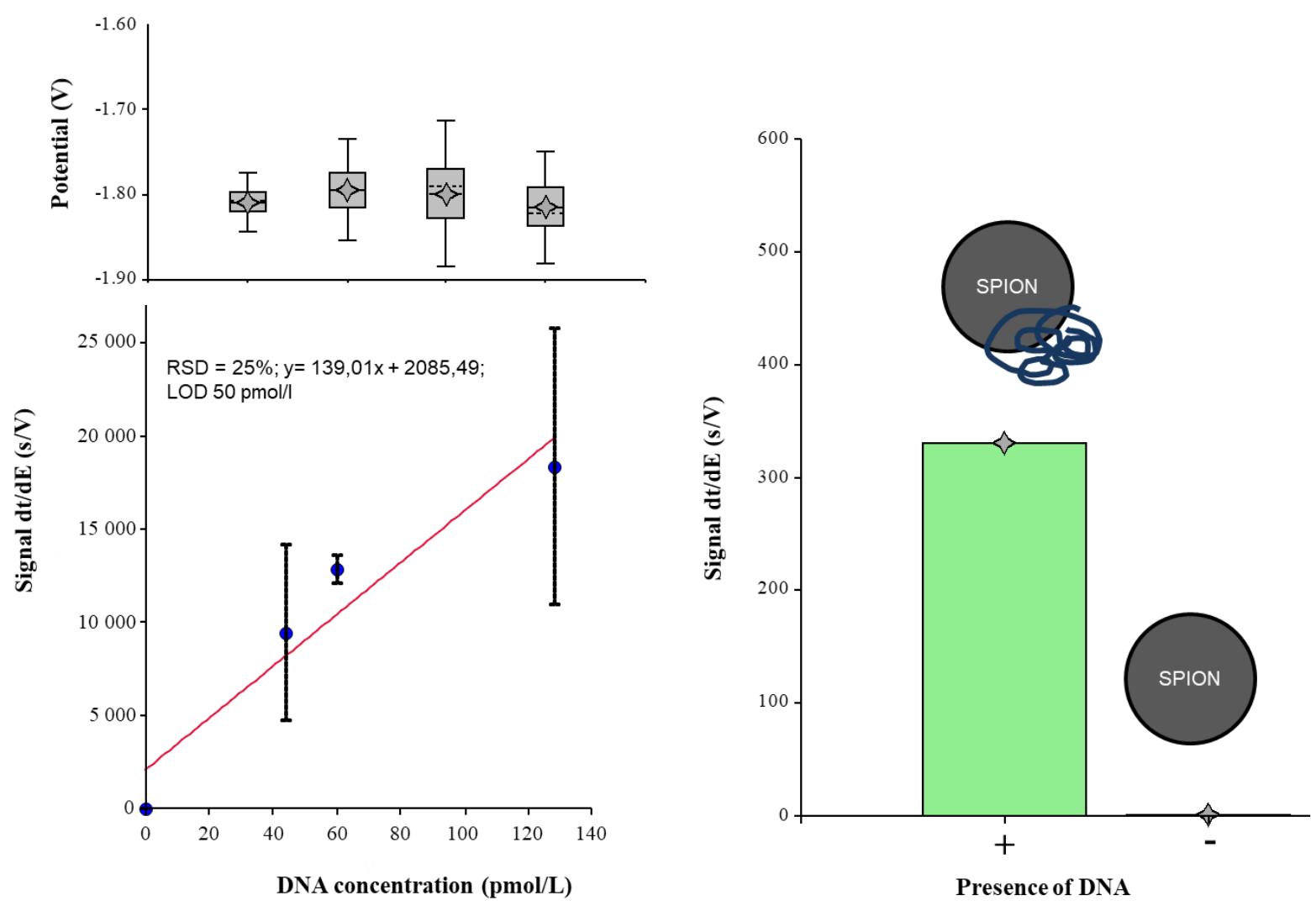

Figure 4 Mean CPSA signals dt/dE dsDNA as a function of concentration and the potential of peak $\mathrm{H}$ (upper part of the figure). Confirmation of the presence of dsDNA captured on SPION particles after their interaction for $240 \mathrm{~s}$ at $300 \mathrm{rpm}$ and $25^{\circ} \mathrm{C}$ in hybridization buffer.

\section{CONCLUSION}

Research in the field of sensors and biosensors for the rapid diagnosis of dangerous pathogens is a highly topical issue. We have found that CPSA can be used to detect ASFV DNA using the catalytic signal of the H peak. The sensitivity of the catalytic signals is significantly higher than the redox signals of nucleic acids. This fact could bring a significant increase in the sensitivity of direct detection of the detected viral pathogen.

\section{ACKNOWLEDGEMENTS}

The study was supported by the project AMOR QK1920113, and by the project of Charles University in Prague (Progress Q26/LF1).

\section{REFERENCES}

[1] KRZYZANKOVA, M., KRASNA, M., BENA, M.,VASICKOVA, P. Virus afrického moru prasat a moznosti jeho sireni masem a masnymi vyrobky. Maso. 2020, vol., no. 1, pp. 32-38. 
[2] PALECEK, E.,JELEN, F. Electrochemistry of nucleic acids and development of DNA sensors. Crit. Rev. Anal. Chem. 2002, vol. 32, no. 3, pp. 261-270.

[3] WANG, J., CAI, X. H., RIVAS, G., SHIRAISHI, H.,DONTHA, N. Nucleic-acid immobilization, recognition and detection at chronopotentiometric DNA chips. Biosens. Bioelectron. 1997, vol. 12, no. 7, pp. 587-599.

[4] PALECEK, E. Oscillographic polarography of highly polymerized deoxyribonucleic acid. Nature. 1960, vol. 188, no. 4751 , pp. 656-657.

[5] PALECEK, E., OSTATNA, V.,PECHAN, Z. Fifty Five Years of Nucleic Acid Electrochemistry. Chem. Listy. 2014, vol. 108 , no. 5 , pp. 490-499.

[6] TRNKOVA, L., STUDNICKOVA, M.,PALECEK, E. Electrochemical-behavior of guanine and its derivatives .1. Fast cyclic voltammetry of guanosine and calf thymus DNA. Bioelectrochem. Bioenerg. 1980, vol. 7, no. 4, pp. 643-658.

[7] BOUSSICAULT, F.,ROBERT, M. Electron transfer in DNA and in DNA-related biological processes. Electrochemical insights. Chem. Rev. 2008, vol. 108, no. 7, pp. 2622-2645.

[8] GARGULAK, M., SEHNAL, K., HOSNDLOVA, B., HOAI, N., DOCEKALOVA, M., OFOMAJA, A., STANKOVA, M., UHLIROVA, D., KEPINSKA, M., MILNEROWICZ, H., FERNANDEZ, C., VACIKOVA, P.,KIZEK, R. 3D-printed CdTe QDs-based sensor for sensitive electrochemical detection of viral particles. In: IEEE International Conference on Sensors and Nanotechnology, 2019, pp. 1-4.

[9] BANAS, D., RYCHLY, O., SALMISTRARO, S., AKSU, A. D., KRZYZANKOVA, M., KIZEK, R.,LTD, T. 2021. Optimization of nucleic acid binding to magnetic particles with the aim of detection of dangerous viruses. In: 12th International Conference on Nanomaterials - Research and Application (NANOCON). Brno, Czech Republic: Tanger, 2020, pp. 324-329.

[10] LIU, Q., MA, B. T., QIAN, N. C., ZHANG, F., TAN, X., LEI, J. L.,XIANG, Y. Structure of the African swine fever virus major capsid protein p72. Cell Res. 2019, vol. 29, no. 11, pp. 953-955.

[11] WANG, N., ZHAO, D. M., WANG, J. L., ZHANG, Y. L., WANG, M., GAO, Y., LI, F., WANG, J. F., BU, Z. G., RAO, Z. H.,WANG, X. X. Architecture of African swine fever virus and implications for viral assembly. Science. 2019, vol. 366, no. 6465, pp. 640-+.

[12] HUBAUX, A.,VOS, G. Decision and detection limits for calibration curves. J. Anal. Chem. 1970, vol. 42, no. 8, pp. 849-855.

[13] CAMPUZANO, S., YANEZ-SEDENO, P.,PINGARRON, J. M. Electrochemical Biosensing for the Diagnosis of Viral Infections and Tropical Diseases. Chemelectrochem. 2017, vol. 4, no. 4, pp. 753-777.

[14] BANAS, D., AKSU, D. A., NOGUERA, V. M., MERT, P., HOSNEDLOVA, B.,KIZEK, R. Electrochemical Study of Quantum Dots-Labeled Oligonucleotide Probes for Detecting Nucleic Acid of African Swine Fever Virus. Chem. Listy. 2020, vol. 114, no. 11, pp. 778-783.

[15] MASARIK, M., KIZEK, R., KRAMER, K. J., BILLOVA, S., BRAZDOVA, M., VACEK, J., BAILEY, M., JELEN, F.,HOWARD, J. A. Application of avidin-biotin technology and adsorptive transfer stripping square-wave voltammetry for detection of DNA hybridization and avidin in transgenic avidin maize. Anal. Chem. 2003, vol. 75, no. 11 , pp. 2663-2669.

[16] KIZEK, R., TRNKOVA, L.,PALECEK, E. Determination of metallothionein at the femtomole level by constant current stripping chronopotentiometry. Analytical Chemistry. 2001, vol. 73, no. 20, pp. 4801-4807.

[17] PALECEK, E.,BARTOSIK, M. Intrinsic Electrocatalysis in DNA. Chemelectrochem, 2018, vol. 5, no. 6, pp. 936942.

[18] KOO, K. M., SINA, A. A., CARRASCOSA, L. G., SHIDDIKY, M. J.,TRAU, M. DNA-bare gold affinity interactions: mechanism and applications in biosensing. Analytical Methods. 2015, vol. 7, no. 17, pp. 7042-7054.

[19] CASTILLO, P. M., JIMENEZ-RUIZ, A., CARNERERO, J. M.,PRADO-GOTOR, R. Exploring Factors for the Design of Nanoparticles as Drug Delivery Vectors. ChemPhysChem. 2018, vol. 19, no. 21, pp. 2810-2828.

[20] GEARHEART, L. A., PLOEHN, H. J.,MURPHY, C. J. Oligonucleotide adsorption to gold nanoparticles: a surfaceenhanced Raman spectroscopy study of intrinsically bent DNA. The Journal of Physical Chemistry B. 2001, vol. 105, no. 50, pp. 12609-12615.

[21] SANDSTRÖM, P., BONCHEVA, M.,AKERMAN, B. Nonspecific and thiol-specific binding of DNA to gold nanoparticles. Langmuir. 2003, vol. 19, no. 18, pp. 7537-7543. 
[22] ZHANG, X., SERVOS, M. R.,LIU, J. Surface science of DNA adsorption onto citrate-capped gold nanoparticles. Langmuir. 2012, vol. 28, no. 8, pp. 3896-3902.

[23] CARNERERO, J. M., JIMENEZ-RUIZ, A., GRUESO, E. M.,PRADO-GOTOR, R. Understanding and improving aggregated gold nanoparticle/dsDNA interactions by molecular spectroscopy and deconvolution methods.

Physical Chemistry Chemical Physics. 2017, vol. 19, no. 24, pp. 16113-16123.

[24] CARNERERO, J. M., MASUOKA, S., BABA, H., YOSHIKAWA, Y., PRADO-GOTOR, R., YOSHIKAWA, K. Decorating a single giant DNA with gold nanoparticles. RSC advances. 2018, vol. 8, no. 47, pp. 26571-26579.

[25] ZINCHENKO, A.,YOSHIKAWA, K. Compaction of double-stranded DNA by negatively charged proteins and colloids. Current Opinion in Colloid \& Interface Science. 2015, vol. 20, no. 1, pp. 60-65.

[26] CARNERERO, J. M., JIMENEZ-RUIZ, A., CASTILLO, P. M., PRADO-GOTOR, R. Covalent and Non-Covalent DNA-Gold-Nanoparticle Interactions: New Avenues of Research. Chemphyschem. 2017, vol. 18, no. 1, pp. $17-33$.

[27] CABAllero, A. B., CARDO, L., ClAiRE, S., CRAIG, J. S., HODGES, N. J., VLADYKA, A., ALBRECHT, T., ROCHFORD, L. A., PIKRAMENOU, Z.,HANNON, M. J. Assisted delivery of anti-tumour platinum drugs using DNA-coiling gold nanoparticles bearing lumophores and intercalators: towards a new generation of multimodal nanocarriers with enhanced action. Chemical science. 2019, vol. 10, no. 40, pp. 9244-9256.

[28] ROBINSON, I., TUNG, L. D., MAENOSONO, S., WÄLTI, C., THANH, N. T. Synthesis of core-shell gold coated magnetic nanoparticles and their interaction with thiolated DNA. Nanoscale. 2010, vol. 2, no. 12, pp. 2624-2630.

[29] DEHGHAN, G., MEHDIPOUR, M., HOSSEINPOUR FEIZI, M. A., TARASI, R., KHOOBI, M.,DASTMALCHI, S. Spectroscopic investigation on the interaction of DNA with superparamagnetic iron oxide nanoparticles doped with chromene via dopamine as cross linker. Nanomedicine Journal. 2018, vol. 5, no. 1, pp. 36-45.

[30] HAN, G., MARTIN, C. T.,ROTELLO, V. M. Stability of gold nanoparticle-bound DNA toward biological, physical, and chemical agents. Chemical Biology \& Drug Design. 2006, vol. 67, no. 1, pp. 78-82.

[31] RAILSBACK, J. G., SINGH, A., PEARCE, R. C., MCKNIGHT, T. E., COLLAZO, R., SITAR, Z., YINGLING, Y. G., MELECHKO, A. V. Weakly Charged Cationic Nanoparticles Induce DNA Bending and Strand Separation. Advanced Materials. 2012, vol. 24, no. 31, pp. 4261-+.

[32] GOODMAN, C. M., CHARI, N. S., HAN, G., HONG, R., GHOSH, P.,ROTELLO, V. M. DNA-binding by functionalized gold nanoparticles: Mechanism and structural requirements. Chemical Biology \& Drug Design. 2006, vol. 67 , no. 4, pp. 297-304. 